\title{
Sota-avioliitot avioerotilaston valossa
}

\author{
Kirjoittanut Aarre Tunkelo.
}

Perhettä nimitetään useimmiten yhteiskunnan soluksi. Vertaus onkin sikäli onnistunut, että perheen piirissä tapahtuu yhteiskunnan nuortuminen ja jälkikaśvun kehittyminen. Perhe on myöskin pienin yhteiskunnallinen elin, jolle itsenäinen toiminta kuuluu.

Perhe syntyy normaalitapauksessa avioliiton kautta. Katsoen avioliiton suureen merkitykseen on yhteiskunta kaikkina aikoina pitänyt velvollisuutenaan antaa määräyksiä sen solmiamisesta ja sen oikeudellisesta asemasta. Avioliiton solmiaminen kuuluukin ihmisen säännölliseen elämänkulkuun, josta syystä se samalla on niitä ilmiöitä, jotka ovat ihmiskunnassa säännöllisesti toistuvia. Se on kuitenkin melko herkkä erinäisille vaikutuksille. Milloin yhteiskuntaelämä poikkeaa syystä tai toisesta säännölliseltä uraltaan, se ilmenee myös väestönmuutosten vaihteluina.

Sota on yhteiskuntaelämää kaikin tavoin järkyttävä ilmiö. Silloin säännöllinen ja rauhallinen elämänkulku katkeaa ja aivan uudet näkökohdat, velvoitukset ja vaikutteet astuvat esiin. Seuraavassa on tarkoituksenani esittää huomioita avioliittojen solmiamisesta sodan aikana sekä miten kestäviä nämä avioliitot ovat olleet.

\section{Mitä käsitämme sanalla sota-avioliitto?}

Olemme tottuneet puhumaan sota-avioliitoista, ja näiden vaiheisiin tahtoisin nyt kohdistaa huomion. Sota-avioliitto-sanan si- 
sällys on jäänyt pakostakin epämääräiseksi. Se voidaan rajoittaa koskemaan vain niitä avioliittoja, jotka sotatilan vuoksi on solmittu ja jotka rauhan olosuhteissa olisivat jääneet syntymättä. On kuitenkin muistettava, että sodankin riehuessa solmitaan avioliittoja, jotka ovat täysin rinnastettavissa rauhanajan normaaliavioliittoihin. Onneksi nämä avioliitot ovat sotavuosinakin muodostaneet enemmistön.

Seuraavassa tarkastamme kaikkia sotavuosina solmittuja avioliittoja. Me emme pysty eroíttamaan näistä erillisiä ryhmiä, siis rauhan oloissa solmittuihin verrattavia ja sotatilan vuoksi solmittuja avioliittoja erikseen. Tyydymme sen vuoksi tarkastamaan kaikkia sotatilan vallitessa solmittuja avioliittoja.

\section{Sotavuosien avioliittoisuudesta.}

Pieni kertaus sotavuosien avioliittoisuudesta lienee paikallaan. Viimeisinä rauhan vuosina, vuosina $1935-38$, oli avioliittoisuus lisääntynyt ja avioliittojen lukumäärä noussut siitä laaksosta, johon se oli pudonnut taloudellisen lamakauden aikana. Vuosittain solmittiin noin 30000 avioliittoa. Vuoden 1939 aikana ei vielä ollut havaittavissa sanottavia muutoksia. Tuon vuoden aikana solmittiin 30614 avioliittoa, eivätkä vuoden viimeisten kuukausien tilastoluvut sanottavasti poikenneet rauhanvuosien vastaavista luvuista. Ylimääräisten kertausharjoitusten aikana ei solmittu paljoakaan avioliittoja, joten ko. kuukausien luvut ovat hieman pienemmät kuin olisi odottanut. Silloin ilmeisesti lykättiin avioliittoaikeita.

Mutta sodan todella puhjettua joulukuussa 1939 alkoi heti seuraavan vuoden alussa vihittävien luku lisääntyä. Tammi-, helmija maaliskuun avioliittoluvut osoittivat nopeaa nousua. Tammikuussa solmittiin 2037 , helmikuussa 2626 ja maaliskuussa 3060 avioliittoa. Nousu oli aikaisempiin vuosiin verrattuna lähes 50 prosenttinen. Vuosina $1931-40$ solmittiin kolmen ensimmäisen kuukauden aikana noin $1 / 6$ koko vuoden- avioliitoista, mutta vuonna 1940 vastavana aikana, siis talvisodan aikana, 1/4 sen vuoden avioliittojen kokonaismäärästä. 
Välirauhan aikana olosuhteet tasaantuivat jossain määrin, ja koska sota oli kestänyt vain satakunta päivää, ei tilastossa voida huomata mitään lykkäytyneiden avioliittojen aiheuttamaa lisäystä ensimmäisten rauhankuukausien aikana.

Kun sitten kesäkuussa 1941 sota leimahti uudelleen, oli tilanne jo toinen. Kesäkuussa, joka muutenkin on meidän maassamme yleisin avioliittokuukausi, vihittiin 5921 paria eli lähes kaksinkertainen määrä rauhanvuosiin verrattuna. Muidenkin kesäkuukausien luvut olivat korkeita. Heinäkuussa vihittiin 4648 , elokuussa 4966 ja syyskuussa 3394 morsiusparia. Tuon vuoden aikana solmittiinkin kaikkiaan 37662 avioliittoa, joista yksin kesä-syyskuun aikana 18929 eli $50.3 \%$.

Seuraavana sotavuonna, vuonna 1942, jäi avioliittoisuus erittäin pieneksi. Silloin solmittiin vain 26891 avioliittoa eli $2 / 3$ edellisen vuoden kokonaismäärästä. Seuraava asetelma ilmaisee lähemmin kunkin vuoden tilastoluvut vuodesta 1941 eteenpäin.

$\begin{array}{ccc}\text { Vuosi } & \text { Avioliittoja } & \begin{array}{c}\text { keskiväkiluvun kymmentä } \\ \text { tuhatta henkeä kohden }\end{array} \\ 1941 & 37662 & 102 \\ 1942 & 26891 & 72 \\ 1943 & 31954 & 86 \\ 1944 & 31535 & 84 \\ 1945 & 44380 & 117 \\ 1946 & 49743 & 130 \\ 1947 & 43518 & 112 \\ 1948 & 38977 & 98 \\ 1949 & 35180 & 88\end{array}$

Sotavuosina 1943 ja 1944 pysytteli avioliittoisuus vielä alhaisena. Ilmeistä oli, että sotatila ja epävarma tulevaisuus esti monen avioliittoaikeen toteutumasta. Ja kuitenkin oli sotakuukausipalkkajärjestelmä omiaan helpottamaan nuorten avioparien taloudellisia vaikeuksia. 
Selvä- muutos tapahtui vasta rauhan palattua. Avioliittotilasto osoittaa, että vihittyjen luku nousi nyt lähes puolentoistakertaiseksi. Tämä muutos tapahtui yhtäkkiä, kuten seuraavat kuukausitiedot solmituista avioliitoista osoittavat.

\section{Vuonna 1945 solmitut avioliitot.}

$\begin{array}{llllll}\text { Tammikuu } & 1591 & \text { Toukokuu } & 3743 & \text { Syyskuu } & 4616 \\ \text { Helmikuu } & 1698 & \text { Kesäkuu } & 5782 & \text { Lokakuu } & 3986 \\ \text { Maaliskuu } & 2394 & \text { Heinäkuu } & 4059 & \text { Marraskuu } & 3947 \\ \text { Huhtikuu } & 2812 & \text { Elokuu } & 3977 & \text { Joulukuu } & 5775\end{array}$

Koko vuonna 44380

Maaliskuussa alkavat kuukausitiedot nopeasti nousta ja pysyvät korkeina vielä seuraavanakin vuonna. Tällöin saavutettiin ennätys: 49743 avioliittoa eli 130 tapausta keskiväkiluvun kymmentätuhatta kohden. Sen jälkeen on avioliittoisuus osoittanut tasaantumisen merkkejä. Sodanjälkeisille vuosille on ominaista myös se, että entistä enemmän on solmittu avioliittoja nuorella iällä. Se johtuu ilmeisesti sodan aiheuttamasta varhaiskypsyydestä ja tällöin vallinneesta täystyöllisyydestä. Taloudelliset edellytykset perheen perustamiseen olivat saavutettavissa hyvin nopeasti. Samaan suuntaan vaikutti myös se, että entistä yleisemmin molemmat aviopuolisot pysyivät ammatissaan jatkuvasti.

On luonnollista, että sota-aikana solmittuja avioliittoja on vaikeata luokitella. Kuitenkin voidaan niistä eroittaa muutamia ryhmiä, jotka ovat tyypillisiä sota-ajan oloille. Tällaisia ovat 1) sellaiset avioliitot, joissa halutaan elämän epävarmuuden vuoksi liittyä yhteen, 2) sellaiset, jotka perustetaan suorastaan määrättyjen taloudellisten etujen vuoksi (sotakuukausipalkan saaminen) ja 3) sellaiset avioliitot, jotka solmitaan nopean ihastuksen aikana liian lyhyen tutustumisajan jälkeen.

Täten solmittiin sotavuosina sellaisia avioliittoja, joiden pysyvyys ei ollut varmaa. Normaalioloissa olisivat niistä monet jääneet toteutumatta. Luonnollisesti on edellä esitettyjenkin perustei- 
den mukaan solmittujen avioliittojen joukossa sellaisia, jotka ovat kestäneet arkielämän ja rauhan aikana. Edelliseen ryhmään kuuluvia tapauksia voimme jossain määrin seurata tarkastamalla avioerotilastoa, jonka valossa näemme sotavuosina solmittujen avioliittojen kestävyyden.

Useat sota-ajan avioliitot rakentuivat liian lyhytaikaiseen ja pintapuoliseen tutustumiseen. Ei ollut mahdollista muuta kuin lyhyiden lomien aikana ottaa selville, sopivatko ajatukset, näkökannat ja elämäntavat yhteen. Sen vuoksi vihittyjen joukossa oli paljon sellaisia pareja, joilla ei ollut mahdollisuuksia kestää rauhanomaisissa oloissa ja tavallisen arkielämän vallitessa. Vasta tällöin huomattiin sellaistakin, mikä sodan temmellyksessä oli ollut taka-alalla. Harmaan arkipäivän probleemithan ovat aivan toisenlaisia kuin sodan vallitessa ja ensilemmen ilossa ajatellaan. Siksi on sodan aikana solmittujen avioliittojen edessä ollut tavallista enemmän vaikeuksia ja niiden joukossa on jo ennakolta voitu arvailla olevan runsaasti sellaisia, jotka väistämättömästi tulisivat jọtamaan avioeroon.

\section{Avioerot.}

Avioliiton purkautumiseen voi olla syynä joko puolison kuolema tai avioero. Edellinen on väestötilastollisesti säännöllinen ilmiö, joka ajallaan kohtaa jokaista avioparia. Sotavuosina se raskaasti verotti perheitämme, koska aviomiesten kuolleisuus sodan johdosta nousi tavattomasti. Avioeron mahdollisuuden taasen on yhteiskunta myöntänyt silloin, kun jatkuvan avioliiton edellytykset ovat särkyneet. Seuraava taulu ilmaisee meille näiden kummankin ilmiön yleisyyden sotavuosina ja sen jälkeen.

$\begin{array}{ccccc}\text { Vuosi } & \begin{array}{c}\text { Purkautuneita aviolittoja } \\ \text { kaikkiaan }\end{array} & \begin{array}{c}\text { Avioerot \%:na } \\ \text { miehen kuole- laillisen avio- } \\ \text { man johdosta } \\ \text { eron johdosta }\end{array} & \begin{array}{c}\text { kaikta purkau- } \\ \text { tuneista avio- } \\ \text { liitoista }\end{array} \\ 1940 & 27765 & 19853 & 1325 & 4.8 \\ 1941 & 28166 & 20714 & 1580 & 5.6 \\ 1942 & 21384 & 13462 & 1954 & 9.1\end{array}$




$\begin{array}{lllll}1943 & 20818 & 11948 & 3166 & 15.2 \\ 1944 & 25692 & 16205 & 3246 & 12.8 \\ 1945 & 23026 & 11766 & 5605 & 24.3 \\ 1946 & 21952 & 11558 & 5164 & 23.5 \\ 1947 & 21597 & 11765 & 4944 & 22.9 \\ 1948 & 20648 & 11168 & 4170 & 20.5 \\ 1949 & 21546 & 12104 & 3784 & 17.6\end{array}$

Lukusarjoja tarkastellessamme huomaamme avioerojen luvuissa kaksi huomattavampaa lisäystä, nimittäin vuosina 1943 ja 1945. Edellisenä vuonna myönnettiin avioeroja jokseenkin puolentoista kertaa niin paljon kuin vuonna 1942 . Tämä tuntuva lisäys antaa aihetta yrittää jakaa avioerot erilaisiin ryhmiin. Osa niistä on laskettava niin sanoakseni normaalisten avioerojen joukkoon, sellaisiin, jotka joka tapauksessa olisivat johtaneet eroon. Näiden lisäksi tulee nyt kaksi uutta avioerojen ryhmää, joissa sota-aika kuvastuu.

Toisen näistä muodostavat ne talvisodan sekä välirauhan aikaiset avioliitot, jotka näin pian olivat kärsineet haaksirikon. Vuonna 1943 myönnettiin avioero 232:lle vuonna 1940 vihitylle ja 273:lle vuonna 1941 vihitylle avioparille. Viimeksimainittujen joukossa on jo jatkosodan alussa vihittyjäkin pareja. Joka tapauksessa nämä luvut ovat huomattavasti korkeampia kuin rauhanvuosina vastaavan ajan kestäneiden avioliittojen kohdalla on todettu. Vielä vuonna 1940 oli avioeroja, joiden avioliitto oli solmittu vuonna 1937, vain 72 ja vuonna 1939 vihittyjen avioeroja 38.

On vaikeata erottaa edellisestä ryhmästä jatkosodan alussa vihittyjä pareja. Mutta lisäksi voimme todeta, että vuonna 1943 ovat kauttaaltaan myös pitemmän aikaa sitten vihittyjen parien avioeroluvut nousseet. Sotatila ja uudet olosuhteet veivät perheet hajalle. Syntyi riitaa aviopuolisoiden välille ja ehkäpä ilmestyi uusi ihastus näköpiiriin. Joka tapauksessa on tällöin avioerojen lukumäärä noussut kauttaaltaan avioliiton kestämisajan mukaan lajiteltuina. Avioerot tulivat yleisemmiksi kuin ennen myös rauhan aikana vihittyjen keskuudessa, joiden kohdalla ne 
avioliittoyuodet, jolloin eniten avioeroja tapahtuu, 6-8. vuosi, olivat jo sivuutetut.

Seuraavana vuonna, vuonna 1944, olivat avioeroluvut suunnilleen samansuuruisia kuin vuonna 1943. Mutta vuonna 1945 havaitsemme jälleen suuren lisäyksen.

Vuonna 1945 myönnettiin yhteensä 5605 avioeroa, joten tällä tavalla päättyi melkein joka neljäs sinä vuonna purkautuneista avioliitoista. Kutakin kolmea kuoleman johdosta purkautunutta avioliittoa kohden tuli siis yksi avioero! Silloin oli rauha jälleen palautunut maahan ja sotapoluilla vuosikausia olleet miehet saivat kotiutua rauhan oloihin. Ei ole ihmeteltävä sitä, että usealla oli vaikea tottua niihin oloihin ja niinpä monen avioparin kohdalle muodostui avioero ainoaksi ulospääsytieksi vaikeuksista.

Vuoden 1945 avioeroista voimme jälleen eroittaa kolme ryhmää: niin sanoakseni »normaalit avioerot», jatko-sodan tällöin purkautuneet avioliitot sekä sodan rappeutuneen moraalin aiheuttamat avioerot. Viimemainittujen joukkoon kuuluu sellaisiakin, joissa ei osattukaan enää asettua rauhanoloihin.

Ensimmäisenä rauhan vuonna purkautui seuraava määrä sotavuosina solmittuja avioliittoja:

Avioliitogn solmimisvuosi

1939

1940

1941

1942

1943

1944
Avioeron saaneita

v. 1945

369

458

625

511

371

201

Huomaamme, että luvut ovat yllättävän suuria. Jos pidämme kaikkia vuosina 1940 -44 solmittuja avioliittoja ns. sota-avioliittojen ryhmään kuuluvina ja laskemme, montako prosenttia tekevät näinä vuosina solmitut ja avioeroon johtaneet avioliitot kunakin vuonna kaikkiaan myönnetyistä avioeroista, niin saamme seuraavan lukusarjan: 
Vuonna 1944 myönnetyistä avioeroista oli $31.3 \%$ vv. 1940-44 solmittuja

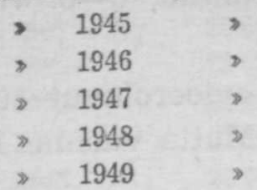

38.6 ,
40.6 ;
41.0 ,
37.8 ;
32.7 ,

Vuosina 1946 ja 1947 muodostivat sotavuosina solmitut avioliitot eron saaneista yli 40 prosenttia. Seuraava taulu yksityiskohtaisesti selvittää, minkä verran eri vuosina solmitut avioliitot ovat vuosina 1938-49 johtaneet avioeroon.

\begin{tabular}{|c|c|c|c|c|c|c|c|c|c|c|c|c|c|}
\hline \multirow{2}{*}{$\begin{array}{l}\text { Avioliitto } \\
\text { solmittu } \\
\text { vuonna }\end{array}$} & \multicolumn{13}{|c|}{ Avioero myönnetty vuonna } \\
\hline & 1937 & 19381 & 1939 & 1940 & 1941 & 1942 & 1943 & 1944 & 1945 & 1946 & 1947 & 19481 & 1949 \\
\hline 1937 & - & 25 & 41 & 72 & 98 & 135 & 207 & 183 & 340 & 270 & 226 & 165 & 151 \\
\hline 1938 & & 7 & 10 & 38 & 90 & 147 & 254 & 208 & 338 & 335 & 237 & 177 & 189 \\
\hline 1939 & & & 2 & 8 & 49 & 116 & 204 & 221 & 369 & 318 & 248 & 201 & 175 \\
\hline 1940 & & & & 3 & 23 & 94 & 232 & 253 & 458 & 351 & 282 & 319 & 212 \\
\hline 1941 & & & & & 4 & 61 & 273 & 379 & 625 & 524 & 462 & 291 & 286 \\
\hline 1942 & & & & & & 18 & 142 & 241 & 511 & 410 & 369 & 278 & 209 \\
\hline 1943 & & & & & & & 23 & 126 & 371 & 438 & 462 & 350 & 257 \\
\hline 1944 & & & & & & & & 17 & 201 & 374 & 450 & 361 & 288 \\
\hline 1945 & & & & & & & & & 19 & 162 & 269 & 402 & 455 \\
\hline 1946 & & & & & & & & & & 18 & 139 & 303 & 426 \\
\hline 1947 & & & & & & & & & & & 25 & 117 & 278 \\
\hline 1948 & & & & & & & & & & & & 5 & 130 \\
\hline
\end{tabular}

Yllä olevassa taulussa kiintyy huomio erityisesti vuonna 1945 myönnettyjen avioerojen suuriin määriin. Nehän ovat kussakin ryhmässä suuremmat kuin minkään muun vuoden vastaavat luvut. Toisaalta taas ilmenee, että vuonna 1941 solmituissa avioliitoissa on ollut jotain erityistä, koska sen vuosiluokan avioliittoja on eri vuosina purkaantunut ennätysmääriä. Vuoden 1949 loppuun mennessä oli näitä jo kertynyt 2905 tapausta, kun esimerkiksi vuonna 1938 solmituista avioliitoista oli vuoden 1949 loppuun asti vain 2030 purkautunut laillisen avioeron kautta. Vuoden 1937 avioliitoista oli vastaavasti purkautunut avioeroina 1913. 
Siirtykäämme sitten tarkastamaan, missä määrin sotavuosina ja sen jälkeen avioliittoja on päättynyt avioeroon avioliittoajan pituuden mukaan. Seuraava taulu osoittaa, montako avioliittoa tuhannesta kunakin vuonna solmitusta on päättynyt avioeroon vihkimisvuonna, seuraavan kalenterivuoden aikana, sitä seuraavan kalenterivuoden aikana jne.

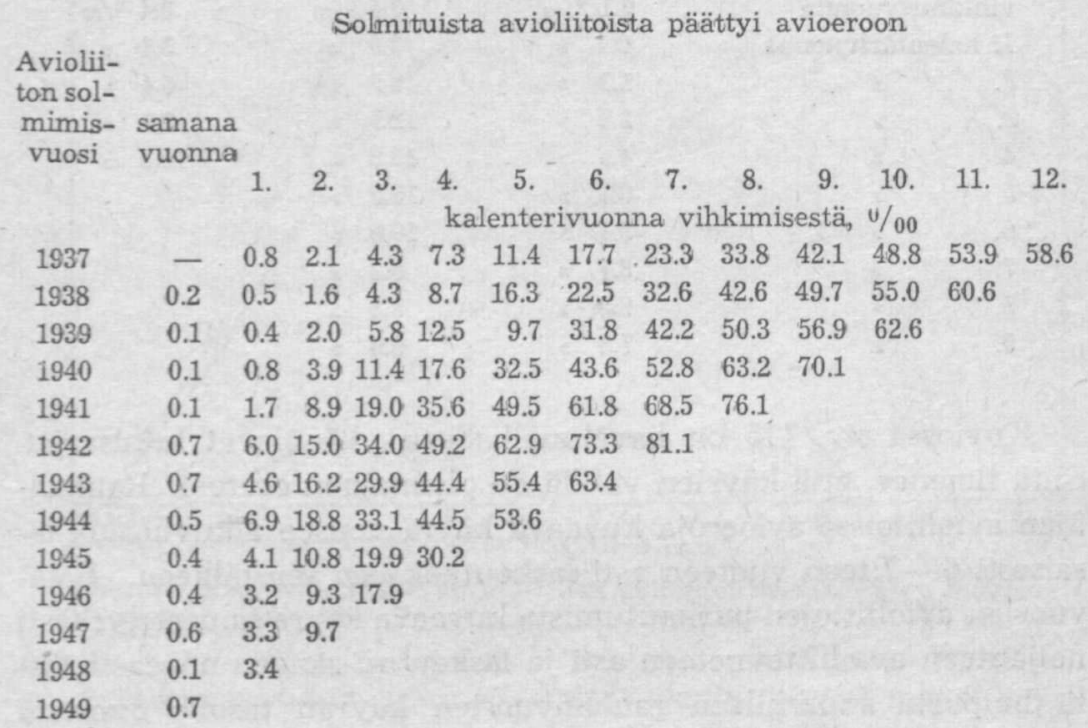

Rauhan vuosina päättyi avioliiton toisen kalenterivuoden loppuun mennessä korkeintaan kaksi avioliittoa tuhannesta. Sotavuosien poikkeukselliset luvut erottuvat selvästi. Avioliittojen alkutaipaleella haaksirikon kärsineiden tapausten suhteellinen määrä nousi jyrkästi tehden toisen kalenterivuoden päättyessä avioliiton solmiamisesta kymmenen-kaksikymmentä tapausta tuhatta solmittua avioliittoa kohden. Sodanjälkeisten vuosien vastaavat luvut ovat jo palaamassa pienemmiksi. Purkautuneiden suhteellinen osuus on kuitenkin edelleen tuntuvasti suurempi kuin ennen sotia.

Seuraavassa on tarkastettu erikseen sotia edeltäneinä vuosina, sotavuosina ja sodan jälkeisinä vuosina solmittujen avioliittojen 
kestävyyttä. Seuraavat lukusarjat ilmoittavat, paljonko vuosina $1937-39,1940$ - 44 ja 1945 - 48 solmituista avioliitoista päättyi vihkimisvuonna sekä seuranneen kalenterivuoden aikana, toisena kalenterivuonna jne.

\begin{tabular}{|c|c|c|c|}
\hline Avioero avioliiton & $\begin{array}{l}\text { Vuosina } 1937 \\
-39 \text { solmitut } \\
\text { avioliitot }\end{array}$ & $\begin{array}{l}\text { Vuosina } 1940 \\
-44 \text { solmitut } \\
\text { avioliitot }\end{array}$ & $\begin{array}{l}\text { Vuosina } 1945 \\
\text {-48 solmitut } \\
\text { avioliitot }\end{array}$ \\
\hline vihkimisvuonna & $0.1 \%$ & $0.4 \%$ & $0.4 \%$ \\
\hline 1. kalenterivuonna & 0.4 & $3.5=$ & $3.1 ?$ \\
\hline 2. & 1.3, & 8.5, & $6.4>$ \\
\hline 3. & $2.9>$ & $12.7=$ & 8.8 \\
\hline 4. & $4.6>$ & 13.3 ? & $10.3=$ \\
\hline 5. & $6.3>$ & 12.5 , & \\
\hline 6. & 8.1 & $10.6=$ & \\
\hline 7. & $8.7>$ & 8.2, & \\
\hline 8. & $9.5>$ & 8.8 & \\
\hline 9. & 7.3 & $6.9=$ & \\
\hline
\end{tabular}

Kuviossa siv. 115 on havainnollistettu yllä olevat lukusarjat. Siitä ilmenee, että käyrien välillä on olennainen erotus. Rauhanajan avioliitoissa avioeroja kuvaava käyrä nousee alkuvuosina tasaisesti 6.-7:teen vuoteen asti laskeutuakseen sen jälkeen. Sotavuosien avioliittojen purkautumista kuvaava käyrä nousee jyrkästi neljänteen avioliittovuoteen asti ja laskeutuu sangen nopeasti tästä huipusta suunnilleen rauhanvuosien käyrän tasolle 8:nnesta avioliittovuodesta alkaen. Sodan jälkeistä käyrää ei voida vielä piirtää pitkällekään, mutta sen alku osoittaa vielä lähes yhtä nopeata nousua kuin avioerojen käyrä sotavuosina.

Aikaisemmin, sotaa edeltävinä vuosina oli suurin avioerojen ryhmä sellaisia, joissa oli oltu naimisissa 5-9 vuotta. Vuosina 1936-40 näitä oli noin $30 \%$ kaikista. Vuosina 1945-47 oli kaikista avioeroista $33 \%$ sellaisia, joiden avioliitto oli kestänyt vain 0 -5 vuotta. Korkeintaan kymmenen vuotta naimisissa olleita oli silloin $64 \%$ kaikista. Vuosina 1936-40 näitä oli ollut lähes puolet, $48 \%$.

On tietysti vaikea sanoa, onko löyhin osa sota-avioliitoista jo purkautunut. Tuntuu kuitenkin siltä, sillä uusimpien vuosien 


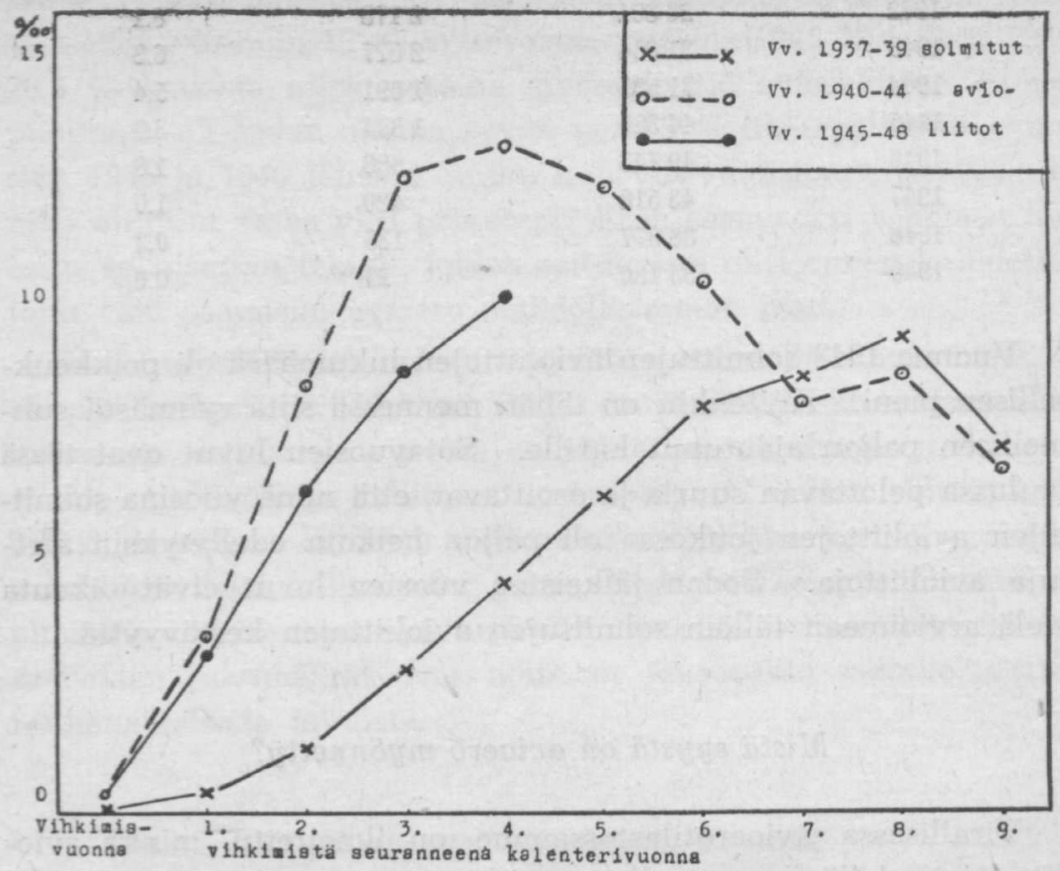

Avioerot \% $\%$ :nä solmituista arvioliitoista avioliiton kestämisajan mukaan.

avioerotilastoissa sotavuosina solmitut avioliitot ovat menettämässä etumatkansa ja siirtymässä suhteellisesti samoille kohdille, joissa rauhanomaisten vuosien avioliitot ovat avioerotilastossa vastaavan ajan voimassa oltuaan. Seuraava taulu ilmaisee, montako vuosina $1937-49$ solmituista avioliitoista on päättynyt avioeroon vuoden 1949 loppuun mennessä.

\begin{tabular}{|c|c|c|c|}
\hline \multirow[t]{2}{*}{ Vuonna } & \multirow[t]{2}{*}{$\begin{array}{l}\text { Solmittuja avio- } \\
\text { liittoja }\end{array}$} & \multicolumn{2}{|c|}{$\begin{array}{l}\text { Vuoden } 1949 \text { loppuun men- } \\
\text { nessä avioeroon johtaneita }\end{array}$} \\
\hline & & luku & $\begin{array}{l}\%: \text { na sinä vuonna } \\
\text { solmituista }\end{array}$ \\
\hline 1937 & 32464 & 1913 & 5.9 \\
\hline 1938 & 33609 & 2080 & 6.0 \\
\hline 1939 & 30614 & 1911 & 6.2 \\
\hline 1940 & 30778 & 2227 & 7.2 \\
\hline 1941 & 37662 & 2905 & 7.7 \\
\hline
\end{tabular}




$\begin{array}{rrrr}1942 & 26891 & 2178 & 8.1 \\ 1943 & 31954 & 2027 & 6.3 \\ 1944 & 31535 & 1691 & 5.4 \\ 1945 & 44380 & 1334 & 3.0 \\ 1946 & 49743 & 886 & 1.8 \\ 1947 & 43518 & 420 & 1.0 \\ 1948 & 38877 & 135 & 0.3 \\ 1949 & 35180 & 21 & 0.0\end{array}$

Vuonna 1942 solmittujen avioliittojen lukumäärä oli poikkeuksellisen pieni. Kuitenkin on tähän mennessä siitä ryhmästä suhteellisen paljon ajautunut karille. Sotavuosien luvut ovat tässä taulussa pelottavan suuria ja osoittavat, että niinä vuosina solmittujen avioliittojen joukossa oli paljon heikoin edellytyksin alettuja avioliittoja. Sodan jälkeisten vuosien luvut eivät oikeuta vielä arvioimaan tällöin solmittujen avioliittojen kestävyyttä.

\section{Mistä syystä on avioero myönnetty?}

Virallisessa avioerotilastossamme on ilmoitettu, minkä avioliittolain pykälän perusteella tuomioistuimet ovat avioeroon myöntyneet. Ei tietystikään aina todellinen avioeron syy tule esille oikeudenkäynnin aikana, mutta jonkinlaista valaistusta tilasto ilmeisesti antaa.

Suurin osa avioeroista myönnetään jatkuvasti sen vuoksi, että aviopuolisot ovat välien rikkoutumisen vuoksi asuneet erossa kaksi viimeistä vuotta. Ennen sotia nämä muodostivat noin $2 / 3$ kaikista tapauksista, vuosina 1936-40 68\%. Sotavuosina ja sen jälkeen on näiden suhteellinen osuus tuntuvasti supistunut pysytellen vuosina 1940 - 42 alle $50 \%$. Vuosina 1945 ja 1946 vastaava prosenttiluku oli vain 41.9 ja 40.7 . Tämä muutos on merkkinä siitä, että halutaan nopeasti päästä irti avioliiton siteistä.

Sotavuosien moraalin huonontuminen ja sopivaisuuskäsitteiden höltyminen on nähtävissä näissä luvuissa. Nyt ovat avioerojen syinä lisääntyneet aviollinen uskottomuus, törkeä pahoinpitely, sukupuolitauti, huumaavien aineiden käyttö jne. Kaikki tällaiset tuodaan nyt häpeilemättä oikeudessa esille, koska siten voidaan 
saada avioero nopeasti. Aviorikosten johdosta myönnettiin vuosina 1936-40 noin $12 \%$ avioeroista, vuosina $194533.4 \%$ ja 1946 $26.8 \%$ kaikista niinä vuosina myönnetyistä avioeroista. Sukupuolitauti oli sodan aikana syynä noin $3 \%$ :iin tapauksista, vuosina 1945 ja 1946 lähes $4 \%$ :iin, kun viisivuotiskautena 1936-40 niitä oli ollut vajaa yksi prosentti. Eron saamiseksi vedetään nyt esille sellaisetkin tekijät, joiden esittämistä olisi ennen kaihdettu, jotta vain saataisiin avioero mahdollisimman pian.

IMistä syystä sitten nykyisin pyritään mahdollisimman mutkattomasti avioeroon? Ehkäpä tähän on löydettävissä vastaus siitä tosiasiasta, että viime vuosina on yhä enemmän avioeron saaneita vihitty uudestaan avioliittoon. Avioero on tullut välttämättömäksi, koska on löydetty uusi »ihastus», jonka kanssa pyritään avioliittoon mahdollisimman pian. Sodan jälkeisinä vuosina on nimittäin todettavissa, että uudestaan avioliittoon menneiden eron saaneiden lukumäärät ovat nousseet jokseenkin nelinkertaisiksi rauhanaikaisista luvuista.

\section{Miltä näyttää lähivuosien kehitys?}

Mutta palatkaamme lopuksi sivulla 115 olevien käyrien pariin. Voimmeko niiden perusteella sanoa jotain lähitulevaisuuden kehityksestä tässä suhteessa? Pysyykö avioerojen määrä jatkuvasti korkeana vai onko odotettavissa, että sota-avioliittojen heikoimman osan purkaannuttua avioerojen lukumäärä alenisi ennen sotia vallinneelle tasolle?

Niin epäkiitollista kuin onkin ryhtyä ennustamaan, lienee kuitenkin pidettävä varmana, että viime vuosina havaittavissa oleva avioerojen väheneminen voi jatkua vielä jonkin aikaa, mutta se pysähtynee tuntuvasti korkeammalle tasolle kuin se oli ennen sotavuosia. Nykyisin on nimittäin monta tekijää, jotka pitävät avioerojen määrää korkealla. Edellä viitatussa taulussa sodan jälkeisten vuosien avioerokäyrä, jota tosin ei ole voitu piirtää vielä pitkällekään, muistuttaa suuresti sotavuosien avioliittojen käyrää. Se merkitsee sitä, että vieläkin on voimakkaita tekijöitä, 
jotka aiheuttavat avioeroja avioliiton alkuvuosina. Näistä mainittakoon vain nykyiset asunto-olot, joiden vuoksi moni nuori pari joutuu kiristämään hermonsa liiankin kireälle. Avioero on nykyisin myös helpommin toteutettavissa, kun nuorella vaimolla on yleensä toimi. Hän voi siis turvallisemmin ajatella avioeroa ja tulevaisuuttaan eron saaneenakin.

Ei myöskään ole luultavaa, että avioerojen määrä sanottavasti pääsee laskemaan nykyisestä. Jos nimittäin yritämme luokitella lähivuosien avioeroa hakevat parit, niin voimme erottaa seuraavat ryhmät: 1) ne tapaukset, jotka normaalisissakin oloissa tulisivat avioeroa anomaan, 2) sota-avioliitoista vielä jokunen määrä, 3) sodan johdosta rikki menneet aviositeet, joita ei vielä ole purettu, 4) sodan loputtua liian äkkiä solmitut avioliitot.

Viimeksi mainittu ryhmä on meillä vaarana. Sen suuruutta on vaikea arvioida, mutta kuten edellä jo viitattiin, on nuorisolla nykyisin helpompi kuin ennen järjestää taloudelliset ynnä muut toimeentulonäkökohdat avioeronkin jälkeen. Tämä voi meillä aiheuttaa yllätyksiä, koska rauhan ensimmäisinä vuosina hyvät toimeentulomahdollisuudet olivat omiaan edistämään avioliittojen solmiamista. Avioliiton vaikeudet ovat nykyisin toiset kuin sotaa edeltäneinä aikoina. 